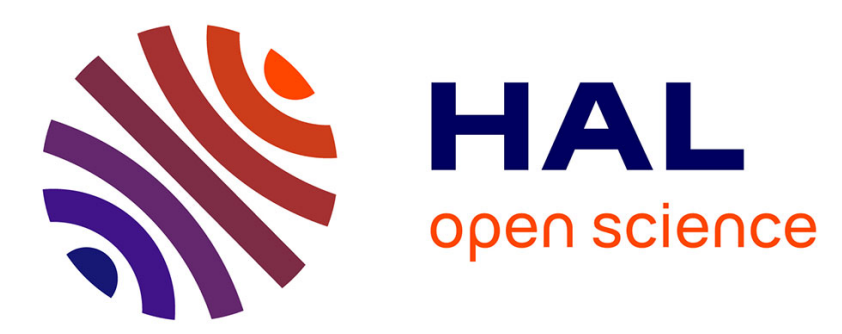

\title{
An electron-rich three dimensional receptor based on a calixarene-tetrathiafulvalene assembly
}

\author{
Joel Lyskawa, David Canevet, Magali Allain, Marc Sallé
}

\section{To cite this version:}

Joel Lyskawa, David Canevet, Magali Allain, Marc Sallé. An electron-rich three dimensional receptor based on a calixarene-tetrathiafulvalene assembly. Tetrahedron Letters, 2010, 51 (45), pp.5868-5872. 10.1016/j.tetlet.2010.08.112 . hal-03344625

\section{HAL Id: hal-03344625 \\ https://univ-angers.hal.science/hal-03344625}

Submitted on 15 Sep 2021

HAL is a multi-disciplinary open access archive for the deposit and dissemination of scientific research documents, whether they are published or not. The documents may come from teaching and research institutions in France or abroad, or from public or private research centers.
L'archive ouverte pluridisciplinaire HAL, est destinée au dépôt et à la diffusion de documents scientifiques de niveau recherche, publiés ou non, émanant des établissements d'enseignement et de recherche français ou étrangers, des laboratoires publics ou privés. 
Provided for non-commercial research and education use. Not for reproduction, distribution or commercial use.

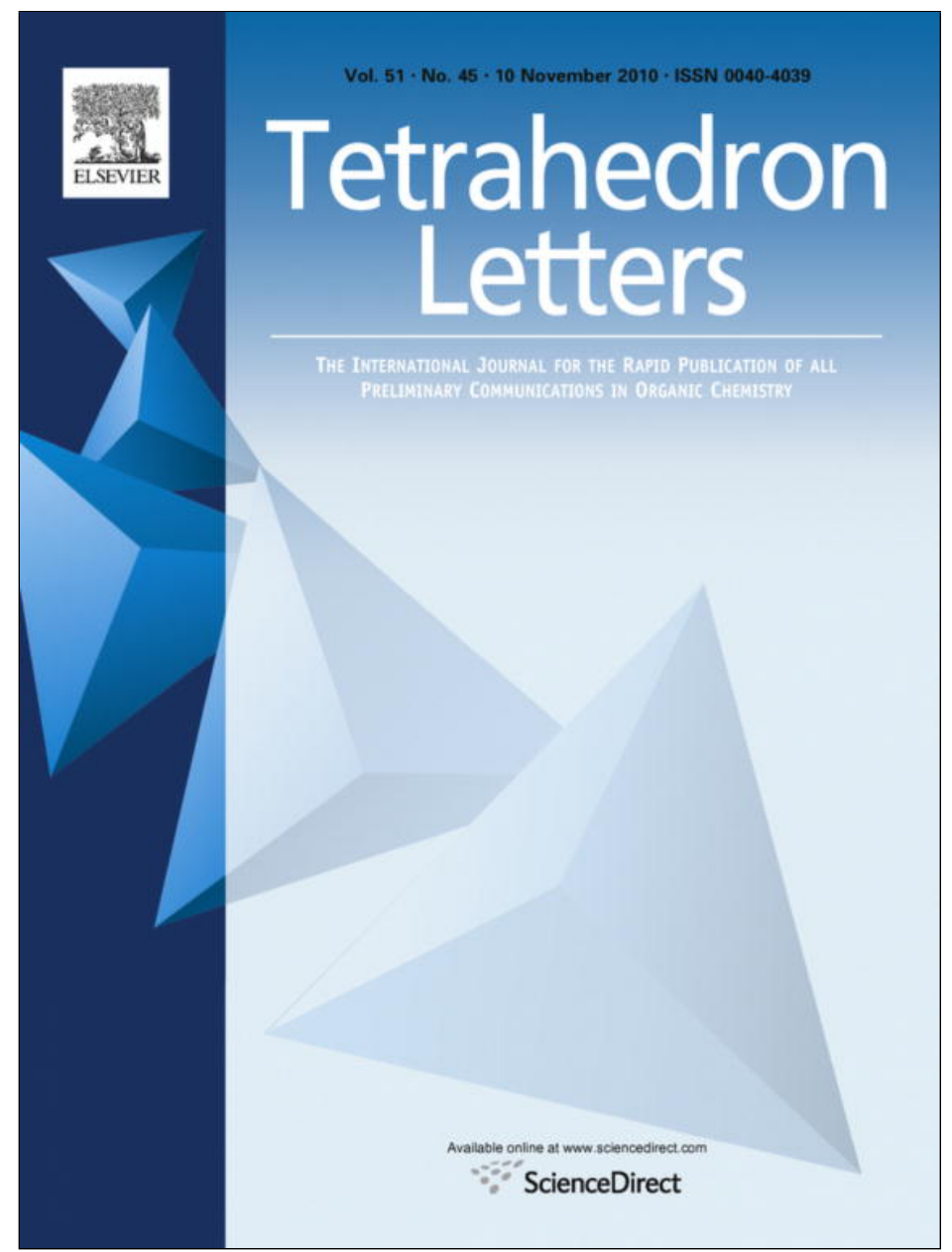

This article appeared in a journal published by Elsevier. The attached copy is furnished to the author for internal non-commercial research and education use, including for instruction at the authors institution and sharing with colleagues.

Other uses, including reproduction and distribution, or selling or licensing copies, or posting to personal, institutional or third party websites are prohibited.

In most cases authors are permitted to post their version of the article (e.g. in Word or Tex form) to their personal website or institutional repository. Authors requiring further information regarding Elsevier's archiving and manuscript policies are encouraged to visit:

http://www.elsevier.com/copyright 


\title{
An electron-rich three dimensional receptor based on a calixarene-tetrathiafulvalene assembly
}

\author{
Joël Lyskawa a,b, David Canevet ${ }^{\mathrm{a}}$, Magali Allain ${ }^{\mathrm{a}}$, Marc Sallé ${ }^{\mathrm{a}, *}$ \\ a Laboratoire MOLTECH-Anjou, UMR CNRS 6200, Université d'Angers, 2 Bd Lavoisier, 49045 Angers, France \\ ${ }^{\mathrm{b}}$ Université Lille Nord de France, Unité des Matériaux et Transformations (UMET, UMR 8207), Equipe Ingénierie des Systèmes Polymères (ISP), Université de Lille 1, \\ F-59655 Villeneuve d'Ascq Cedex, France
}

\section{A R T I C L E I N F O}

\section{Article history:}

Received 26 June 2010

Revised 4 August 2010

Accepted 31 August 2010

Available online 9 September 2010

\section{Keywords:}

Tetrathiafulvalene

Calixarene

Redox-responsive ligand

Electrochemical

Dynamic receptor

\begin{abstract}
A B S T R A C T
The synthesis of a calix[4]arene scaffold persubstituted with four redox-active tetrathiafulvalene (TTF) moieties at the lower rim is described. This assembly strongly binds sodium cation, and the binding process is accompanied by a conformational change of the receptor, as shown from NMR titration and by an $\mathrm{X}$-ray diffraction led on the complex. This dynamic behavior remarkably results in a modification of the electrochemical response of TTF probes, which behave independently after sodium complexation.
\end{abstract}

(c) 2010 Elsevier Ltd. All rights reserved.
Efforts are continuously produced for molecular systems capable of sensing charged or neutral substrates. An important class of receptors is based on redox-responsive ligands built from the association of a binding subunit with a redox-active moiety. ${ }^{1-5}$ Many recent examples incorporate the electroactive tetrathiafulvalene (TTF) unit. ${ }^{6-17}$ Indeed, TTF derivatives display a remarkable electrochemical behavior, supported by a high $\pi$-donating ability, and a good reversibility of the two successive one electron redox processes. In such responsive ligands, complexation of a guest leads to an electrochemical detection generally occurring through electrostatic interaction between the bound ion and the redox probe. Besides, rare examples of TTF-based receptors allow a recognition process based on a conformational change, and in those cases, the receptors present conformationally flexible structures built for example around a biphenyl relay ${ }^{18}$ or a vinylogous TTF skeleton. ${ }^{19}$ On the other hand, $p$-tert-butylcalix[4]arene tetraesters are known for their ability to bind alkaline cations. ${ }^{20}$ In particular, it appears that p-tert-butylcalix[4]arene tetraethyl esters in cone conformation 1a, strongly bind sodium cation through contribution of the four $O$-phenolate atoms and the four carbonyl groups (Scheme 1). Consequently, whereas free ligand 1a presents a distorted cone conformation in the crystal, ${ }^{21} \mathrm{X}$-ray structure of the corresponding 1a- $\mathrm{Na}^{+}$complex exhibits a highly symmetrical locked structure, promoted by the octa-coordinated metal cation. ${ }^{22}$

\footnotetext{
* Corresponding author. Tel.: +33 241735 439; fax: +33 241735405 .

E-mail address: marc.salle@univ-angers.fr (M. Sallé).
}

On this ground, we were interested in evaluating how replacement of ethyl fragments in $\mathbf{1 a}$ by redox-active TTF units (compound $\mathbf{1 b}$ ), could be translated in an electrochemical response upon sodium cation binding. Several examples associating a calixarene platform to redox-active ferrocene units have already been described, and have been used for anion sensing. ${ }^{23-28}$ From this point of view, a TTF-based receptor would also be interesting, given the peculiar electronic properties of this moiety. In addition, though electronrich receptors incorporating polyaromatic platforms and TTF units have been the subject of intense interest in the recent years, ${ }^{29-36}$ no example of calixarene persubstituted with TTF units has been described so far. We propose herein the synthesis of receptor $\mathbf{1 b}$, as well as a study of $\mathrm{Na}^{+}$binding over the conformational and electrochemical behaviors of this electron-rich receptor, including the solid state characterization of the sodium complex.

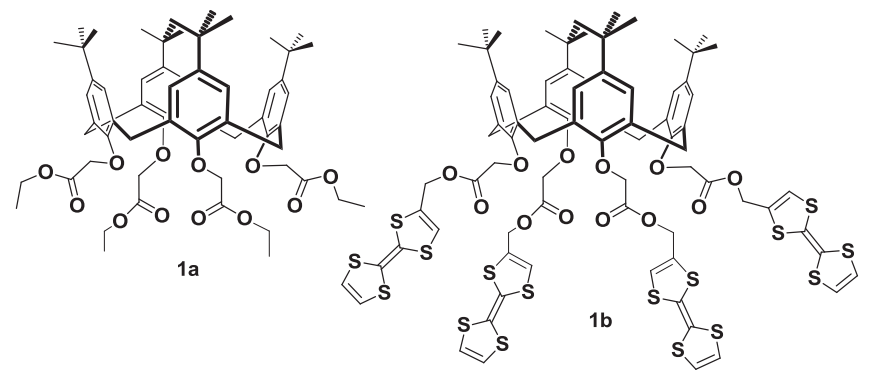

Scheme 1. Target system $\mathbf{1 b}$. 

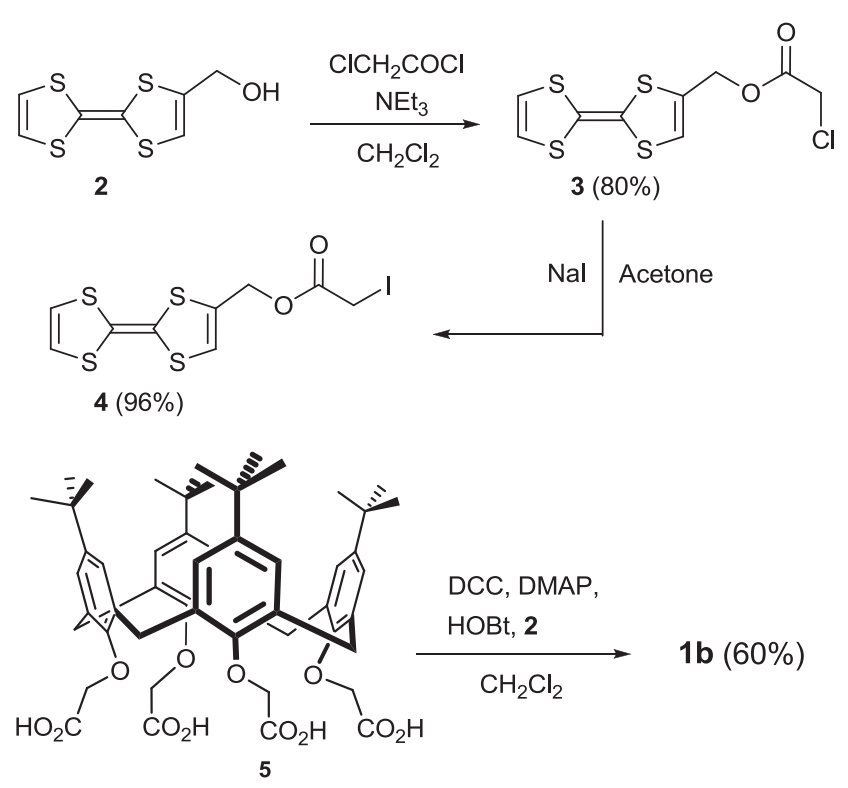

Scheme 2. Synthetic access to $\mathbf{1 b}$.

Two synthetic routes were explored to reach the target calixarene derivative $\mathbf{1 b}$ (Scheme 2 ). Hydroxymethyl-TTF $\mathbf{2}^{37,38}$ was successively converted to the corresponding chloroacetate derivative 3 by reaction with 2-chloroacetyl chloride in presence of an excess of triethylamine ( $80 \%$ yield), and to the iodoacetate analog 4 by refluxing with $\mathrm{NaI}$ (acetone). Various attempts to couple this building block to $p$-tert-butylcalix[4]arene failed, either using sodium hydride or potassium carbonate as a base and/or heating the mixture. Whatever the conditions, ester $\mathbf{4}$ was systematically hydrolyzed regenerating the starting hydroxymethyl-TTF 2 . We therefore synthesized tetraacid calixarene derivative $\mathbf{5}$, according to the described procedure. ${ }^{20}$ Tetraesterification to $\mathbf{1 b}$ could then be successively carried out with hydroxymethyl-TTF 2 , in presence of dicyclohexylcarbodiimide (DCC), 4-(N, N-dimethylamino)pyridine and hydroxybenzotriazole (HOBt). Under these conditions, the target compound $\mathbf{1 b}$, which associates four TTF units with the calixarene platform, was isolated as a yellow solid in a $60 \%$ yield.

NMR signals of $\mathbf{1 b}$ could be fully assigned on the basis of HMQC and HMBC studies. This compound exists in a cone conformation which is characterized by a pair of doublets for diastereotopic

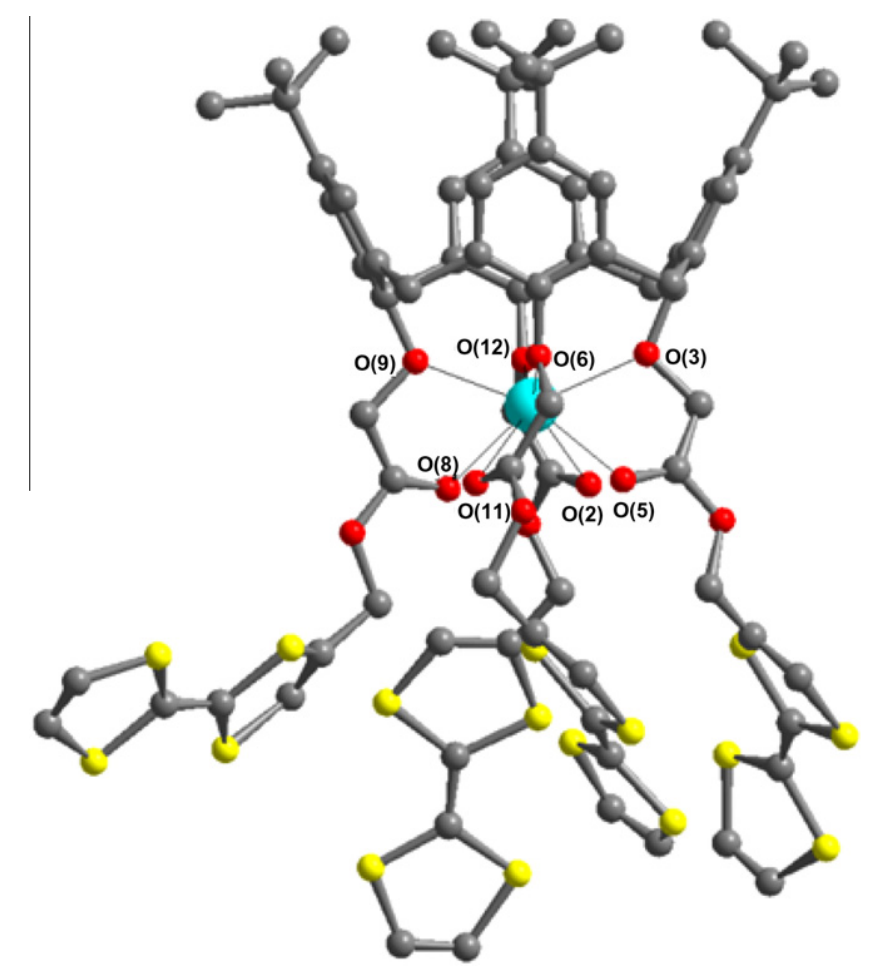

Figure 2. X-ray structure of $\mathbf{1 b}-\mathrm{NaPF}_{6}\left(\mathrm{CH}_{2} \mathrm{Cl}_{2}\right)_{1.5}$ (solvent and anion omitted).

$\mathrm{ArCH}_{2} \mathrm{Ar}\left(\mathrm{H}_{\mathrm{f}}\right.$ protons) (Fig. 1). In addition, only one kind of aromatic $\left(\mathrm{H}_{\mathrm{h}, \mathrm{g}}\right)$ and tert-butylic protons is found, which agrees with a symmetric $C_{4 \mathrm{v}}$ cone conformation. The cone appears significantly closed since $\Delta\left[\left(\delta_{\mathrm{f} 1}\right)-\Delta\left(\delta_{\mathrm{f} 2}\right)\right]=4.71-3.21=1.50 \mathrm{ppm}^{39}$

The conformational modification of this system upon binding of an alkaline cation could be monitored by ${ }^{1} \mathrm{H}$ NMR. The progressive introduction of $\mathrm{NaClO}_{4}$ aliquots onto $\mathbf{1 b}\left(\mathrm{CD}_{3} \mathrm{CN}-\mathrm{CD}_{2} \mathrm{Cl}_{2}\right)$ results in the appearance of a new set of signals and the concomitant disappearance of those of free $\mathbf{1 b}$. This observation is assigned to the progressive formation of a complex in slow exchange with free ligand $\mathbf{1 b}$ at the NMR time scale. Such observation constitutes a first evidence of the high affinity of receptor $\mathbf{1}$ for $\mathrm{Na}^{+}$. Noteworthy, no additional change is observed for NMR spectra carried out with an excess of $\mathrm{NaClO}_{4}$ related to $\mathbf{1 b}$, in agreement with a $1 / 1$ stoichiometry $\left((\mathbf{1 b})_{1}\left(\mathrm{NaClO}_{4}\right)_{1}\right)$. Moreover, the most affected protons upon $\mathrm{Na}^{+}$binding, are those belonging to calixarene ring $\left(\mathrm{H}_{\mathrm{h}, \mathrm{g}}, \mathrm{H}_{\mathrm{f} 1, \mathrm{f} 2}\right)$,
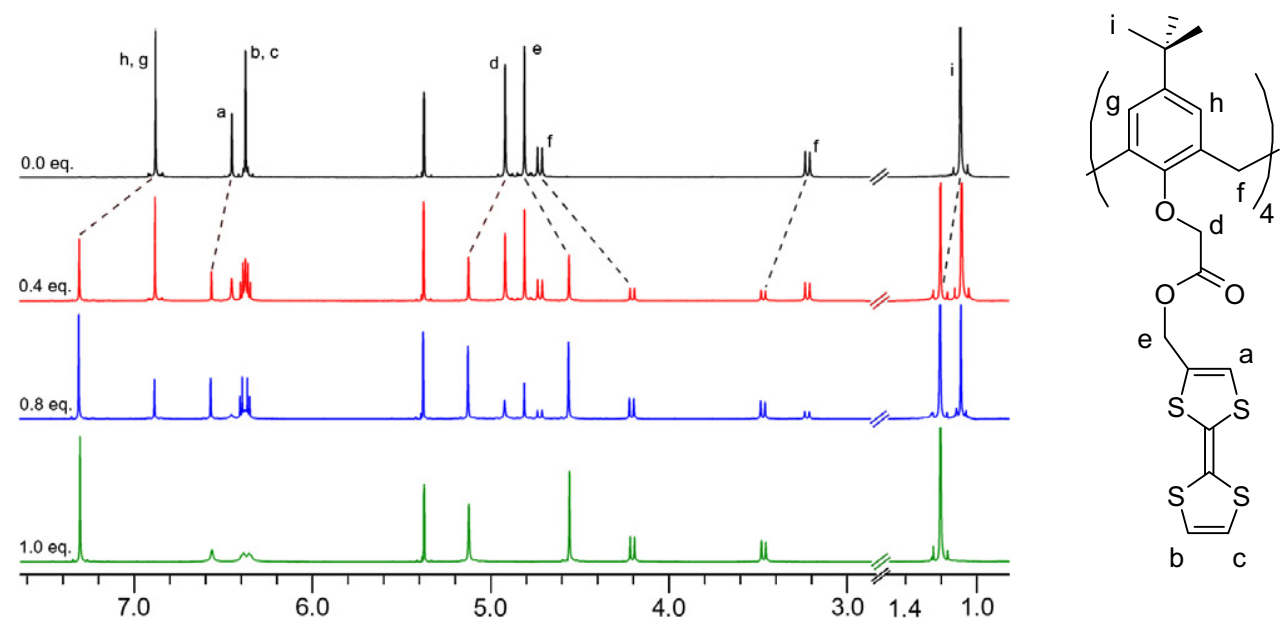

Figure 1. ${ }^{1} \mathrm{H}$ NMR spectrum of compound $\mathbf{1 b}\left(C=9.1 \times 10^{-3} \mathrm{~mol} / \mathrm{L}, \mathrm{CD}_{3} \mathrm{CN}-\mathrm{CD}_{2} \mathrm{Cl}_{2}, 1: 1\right)$ in presence of increasing amounts of $\mathrm{NaClO}_{4}$. 
Table 1

$\mathrm{Na}-\mathrm{O}$ distances in $\mathbf{1 b}-\mathrm{NaPF}_{6}$ complex

\begin{tabular}{ll}
\hline $\mathrm{O}(02)-\mathrm{Na}$ & $2.44(1)$ \\
$\mathrm{O}(03)-\mathrm{Na}$ & $2.45(1)$ \\
$\mathrm{O}(05)-\mathrm{Na}$ & $2.85(1)$ \\
$\mathrm{O}(06)-\mathrm{Na}$ & $2.45(1)$ \\
$\mathrm{O}(08)-\mathrm{Na}$ & $2.45(1)$ \\
$\mathrm{O}(09)-\mathrm{Na}$ & $2.43(1)$ \\
$\mathrm{O}(11)-\mathrm{Na}$ & $2.83(1)$ \\
$\mathrm{O}(12)-\mathrm{Na}$ & $2.50(1)$ \\
\hline
\end{tabular}

and at a lower extent, those belonging to appended ester arms $\left(\mathrm{H}_{\mathrm{d}}\right.$ $\mathrm{H}_{\mathrm{e}}$ ). On the other hand, TTF protons are mostly unaffected. These observations suggest a binding process through oxygen atoms which results in a more rigid cone, as promoted by $\mathrm{Na}^{+}$octa-coordination. A significant decrease of $\Delta\left(\delta_{\mathrm{f} 1}-\delta_{\mathrm{f} 2}\right)$ is observed upon sodium complexation $(0.74 \mathrm{ppm})$ compared to $1.50 \mathrm{ppm}$ for the free ligand $\mathbf{1 b}$, which is indicative of a more opened cone cavity. ${ }^{39}$ Therefore, the cone shape persists (two doublets for $\mathrm{ArCH}_{\mathrm{f} 1} \mathrm{H}_{\mathrm{f} 2} \mathrm{Ar}$ ), but the volume of the binding cavity has increased in order to receive the sodium cation. Finally, receptor $C_{4 \mathrm{v}}$ symmetry is maintained in the complex, as shown by occurrence of only one set of signals for aromatic $\left(\mathrm{H}_{\mathrm{h}, \mathrm{g}}\right)$ and tert-butyl protons.

Yellow single crystals of the corresponding sodium complex could be obtained by slow diffusion of a dichloromethane-acetonitrile solution of ligand $\mathbf{1 b}$ into a methanol solution containing sodium hexafluorophosphate. The complex crystallizes in the $P \overline{2}_{1} / c$ space group with 1.5 molecules of $\mathrm{CH}_{2} \mathrm{Cl}_{2}$, and four molecules of $\mathbf{1 b}$ are found per unit ( $\left.\mathbf{1 b}-\mathrm{NaPF}_{6}\left(\mathrm{CH}_{2} \mathrm{Cl}_{2}\right)_{1.5}\right)$ (Fig. 2). The calixarene part clearly adopts a symmetrical cone conformation in the solid state, in accordance with solution NMR data. The cone characteristics are very similar to the ones observed for the previously described $\mathrm{Na}^{+}$complexes of $p$-tert-butylcalix[4]arene tetraethyl ester $1 a^{8}{ }^{8}$ which indicates that the introduction of four bulky TTFCH ${ }_{2}$ units does not perturb the binding process of $\mathrm{Na}^{+}$. The sodium cation occupies the center of the cavity formed by the four pendant $\mathrm{Ar}-\mathrm{O}-\mathrm{CH}_{2}-\mathrm{C}(\mathrm{O})-\mathrm{X}$ groups, and is octa-coordinated according to an antiprism mode, by the four oxygen atoms from the phenate rings and the four oxygen atoms from the carbonyl groups (see $\mathrm{Na}-\mathrm{O}$ distances in Table 1 ). Six $\mathrm{Na}-\mathrm{O}$ distances are comprised between 2.43 and $2.50 \AA$, and the other two, involving carbonyl groups, are higher (2.83-2.85 $)$. Two TTF planes are nearly parallel within the molecule, with S ...S inter-TTF distances in the range of $3.95 \AA$ (Fig. 3). The corresponding TTF dimer stacks with another dimer from the next calix-TTF system, with $\mathrm{S} \ldots \mathrm{S}$ inter-TTF distances of $3.76 \AA$, thus giving rise to a TTF stack along the $c$ axis. Finally, the two residual TTF units of the receptor are engaged in short S...S intermolecular distances (3.56 $\AA$ ), a value which is significantly lower than the sum of the sulfur van der Waals radius $(3.70 \AA$ ) $)$. Altogether, this combination of interactions leads to a crystallographic organization where slabs of sulfur rich (TTF) units are alternated with slabs of calixarene units along the $b$ axis. The anion and solvent molecules are localized near ester-appended residues, between calixarene and TTF units.

Receptor 1b bears four electroactive TTF units whose electrochemical signature can be characterized by cyclic voltammetry and which can be potentially affected upon sodium binding. The parent TTF unit is known to be reversibly oxidized according to two successive one electron redox processes, giving rise to stable cation-radical and dication species. The cyclic voltammogram of 1b shows the presence of two quasi-reversible electrochemical processes. The first redox process appears split in two waves (Fig. 4a), which is even more evident from the deconvoluted CV (Fig. 4b). As already described for several covalent poly-TTF systems, ${ }^{30,32,35,40-44}$ the first oxidation to the poly(radical-cation) state is broadened or split because of intramolecular interactions between pendant TTF units. This originates from an electronic stabilization of the first formed radical cation by a neighboring TTF unit. On the contrary, the second redox process $\left(\mathrm{E}_{\mathrm{ox}}^{2}=0.73 \mathrm{~V}\right)$ presents an expected electrochemical feature for independent TTF units and corresponds to a full oxidation to $\mathbf{1 b}^{8+}$. This indicates that TTF units are at a larger distance and no longer in electronic

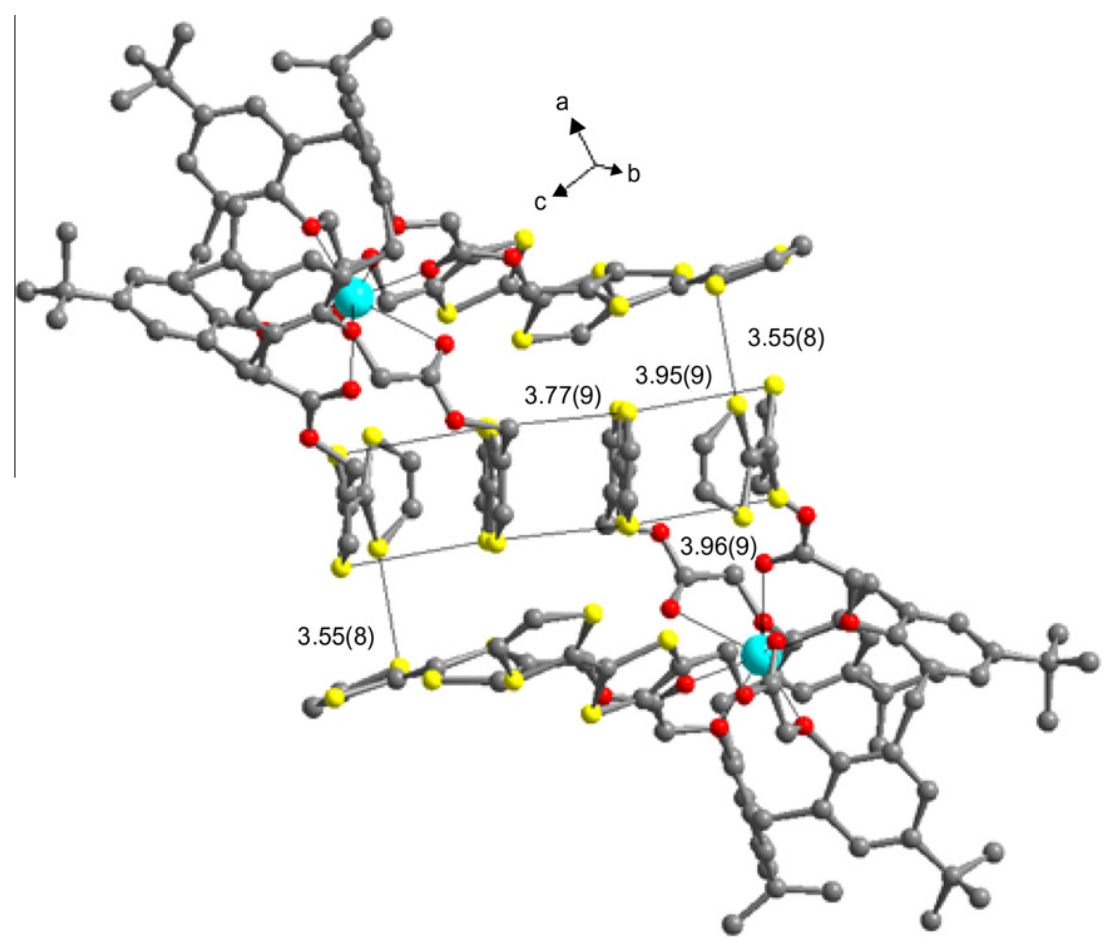

Figure 3. X-ray structure of $\mathbf{1 b}-\mathrm{NaPF}_{6}\left(\mathrm{CH}_{2} \mathrm{Cl}_{2}\right)_{1.5}$, showing intermolecular $\mathrm{S} \cdots \mathrm{S}$ distances (anion and solvent not presented for clarity) and illustrating alternation between $\mathrm{S}$ rich and calixarene slabs. 

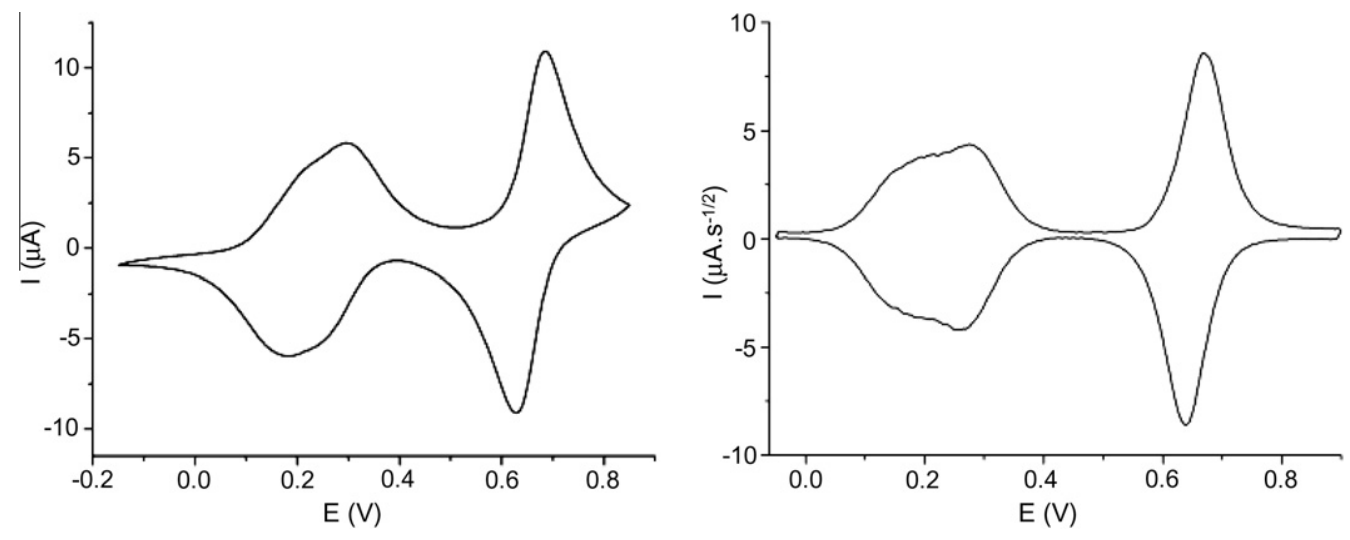

Figure 4. (a) Cyclic voltammogram (CV) of $\mathbf{1 b}$; (b) deconvoluted $\mathrm{CV}$ of $\mathbf{1 b}$; $[\mathbf{1 b}]=5 \times 10^{-4} \mathrm{~mol} / \mathrm{L}, \mathrm{TBAPF}_{6} 0.1 \mathrm{M}, v=100 \mathrm{mV} / \mathrm{s}$ versus Ag/AgCl, acetonitrile/CH${ }_{2} \mathrm{Cl}_{2}(1: 1), \mathrm{Pt}$, $\varnothing=1.6 \mathrm{~mm}$.

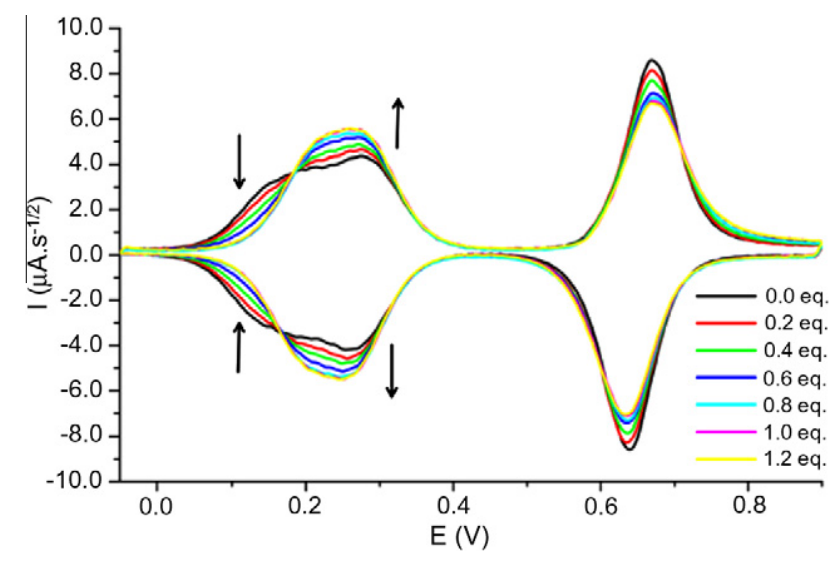

Figure 5. Deconvoluted $\mathrm{CV}$ of $\mathbf{1 b}$ in presence of increasing amounts of sodium perchlorate; [1 b] $=5 \times 10^{-4} \mathrm{~mol} / \mathrm{L}, \mathrm{TBAPF}_{6} 0.1 \mathrm{M}, v=100 \mathrm{mV} / \mathrm{s}$ versus $\mathrm{Ag} / \mathrm{AgCl}$, acetonitrile $/ \mathrm{CH}_{2} \mathrm{Cl}_{2}$ (1:1), Pt, $\varnothing=1.6 \mathrm{~mm}$. Acetonitrile $/ \mathrm{CH}_{2} \mathrm{Cl}_{2}(1: 1)$. Pt, $\varnothing=1.6 \mathrm{~mm}$.

communication. Such behavior has already been depicted with various poly-TTF systems, and is supported by conformational changes resulting from electrostatic repulsive interactions between $\mathrm{TTF}^{2+}$ units. In a way, our system behaves as a flower which is closed (TTF units in interactions around the calixarene ring), and whose petals (TTF units) spread away upon a stimulus (oxidation to the $\mathbf{1 b}^{8+}$ state). This behavior is confirmed by geometry optimization (MM+, Hyperchem 7.5) led on the neutral compound $\mathbf{1}$ (closed flower) and $\mathbf{1}^{8+}$ (opened flower) (Supplementary data).

Introduction of aliquots of $\mathrm{MClO}_{4}(\mathrm{M}=\mathrm{Li}, \mathrm{Na})$ results in a narrowing of the first redox process, whereas no change is observed on the second system (Fig. 5 and Supplementary data). The thinner shape of the first redox wave for the sodium complex relative to free receptor $\mathbf{1}$, is assigned to the conformational reorganization which occurs upon cation binding, as anticipated from the above NMR data. The rigidity gained by the system does not authorizeor at least decrease-interactions between TTF units, which now are close to behave as independent redox units. Therefore, the electrochemical response to cation binding does not result in this case from electronic effects but rather from a conformational change induced by cation complexation.

In summary, we have presented a synthetic access to a calix[4]arene platform persubstituted with four redox-active TTF units. This system strongly binds one sodium cation as shown by NMR studies. This complexation rigidifies the calixarene moiety in a symmetrical conformation whose X-ray structure could be solved.
The conformational change can be followed by a modification of the electrochemical response of appended TTF redox-active units.

\section{Acknowledgment}

This work has been partly financially supported by ANR-PNANO (ANR-07-NANO-030-01) which is acknowledged.

\section{Supplementary data}

Supplementary data (experimental procedures and NMR spectra for compounds $\mathbf{1 b}, \mathbf{3}, \mathbf{4}$; X-ray data for $\mathbf{1 b}-\mathrm{NaPF}_{6}$; CV titration studies of $\mathbf{1 b}$ in presence of $\mathrm{LiClO}_{4}$. Geometry optimization of $\mathbf{1}$ and $\mathbf{1}^{8+}$ ) associated with this article can be found, in the online version, at doi:10.1016/j.tetlet.2010.08.112.

\section{References and notes}

1. Kaifer, A. E.; Mendoza, S.. In Advances in Comprehensive Supramolecular Chemistry; Atwood, J. L., Davies, J. E., MacNicol, D. D., Vögtle, F., Eds.; Pergamon: Oxford, 1996; Vol. 1, pp 701-732.

2. Boulas, P. L.; Gómez-Kaifer, M.; Echegoyen, L. Angew. Chem., Int. Ed. 1998, 37, 216-247.

3. Beer, P. D.; Gale, P. A.; Chen, G. Z. Coord. Chem. Rev. 1999, 185-186, 3-36.

4. Beer, P. D.; Gale, P. A.; Chen, G. Z. J. Chem. Soc., Dalton Trans. 1999, 1897-1909.

5. Bernhardt, P. V.; Moore, E. G. Aust. J. Chem. 2003, 56, 239-258.

6. Canevet, D.; Sallé, M.; Zhang, G.; Zhang, D.; Zhu, D. Chem. Commun. 2009, 22452269.

7. Bryce, M. R. J. Mater. Chem. 2000, 10, 589-598.

8. Nielsen, M. B.; Lomholt, C.; Becher, J. Chem. Soc. Rev. 2000, 29, 153-164.

9. Martín, N.; Segura, J. L. Angew. Chem., Int. Ed. 2001, 40, 1372-1409.

10. Jeppesen, J. O.; Becher, J. Eur. J. Org. Chem. 2003, 17, 3245-3266.

11. Lyskawa, J.; Le Derf, F.; Levillain, E.; Mazari, M.; Sallé, M.; Dubois, L.; Viel, P.; Bureau, C.; Palacin, S. J. Am. Chem. Soc. 2004, 126, 12194-12195.

12. Trippé, G.; Canevet, D.; Le Derf, F.; Frère, P.; Sallé, M. Tetrahedron Lett. 2008, 49, 5452-5454.

13. Balandier, J.-Y.; Belyasmine, A.; Sallé, M. Eur. J. Org. Chem. 2008, 269-276.

14. Benhaoua, C.; Mazari, M.; Mercier, N.; Le Derf, F.; Sallé, M. New J. Chem. 2008, 32, 913-916.

15. Zhao, Y. P.; Wu, L. Z.; Si, G.; Liu, Y.; Xue, H.; Zhang, L. P.; Tung, C. H. J. Org. Chem. 2007, 72, 3632-3639.

16. Dolder, S.; Liu, S. X.; Le Derf, F.; Sallé, M.; Neels, A.; Decurtins, S. Org. Lett. 2007, 9, 3753-3756.

17. Xue, H.; Tang, X.-J.; Wu, L.-Z.; Zhang, L.-P.; Tung, C.-H. J. Org. Chem. 2005, 70, 9727-9734.

18. Delogu, G.; Fabbri, D.; Dettori, M. A.; Sallé, M.; Le Derf, F.; Blesa, M. J.; Allain, M. J. Org. Chem. 2006, 71, 9096-9103.

19. Massue, J.; Bellec, N.; Guerro, M.; Bergamini, J. F.; Hapiot, P.; Lorcy, D. J. Org. Chem. 2007, 72, 4655-4662.

20. Arnaud-Neu, F.; Barrett, G.; Cremin, S.; Deasy, M.; Ferguson, G.; Harris, S. J.; Lough, A. J.; Guerra, L.; McKervey, M. A.; Schwing-Weill, M. J.; Schwinte, P. J. Chem. Soc., Perkin Trans. 2 1992, 1119-1125.

21. Arnaud-Neu, F.; Collins, E. M.; Deasy, M.; Ferguson, G.; Harris, S. J.; Kaitner, B.; Lough, A. J.; McKervey, M. A.; Marques, E. J. Am. Chem. Soc. 1989, 111, 86818691 . 
22. Wickens, J.; Dryfe, R. A. W.; Mair, F. S.; Pritchard, R. G.; Hayes, R.; Arrigan, D. W. M. New J. Chem. 2000, 24, 149-154.

23. Beer, P. D.; Hayes, E. J. Coord. Chem. Rev. 2003, 240, 167-189.

24. Beer, P. D.; Cadman, J. Coord. Chem. Rev. 2000, 205, 131-155.

25. Gale, P. A.; Chen, Z.; Drew, M. G. B.; Heath, J. A.; Beer, P. D. Polyhedron 1998, 17 405-412.

26. Evans, A. J.; Matthews, S. E.; Cowley, A. R.; Beer, P. D. Dalton Trans. 2003, 46444650.

27. Métay, E.; Duclos, M. C.; Pellet-Rostaing, S.; Lemaire, M.; Schulz, J.; Kannappan, R.; Bucher, C.; Saint-Aman, E.; Chaix, C. Eur. J. Org. Chem. 2008, 4304-4312.

28. Métay, E.; Duclos, M. C.; Pellet-Rostaing, S.; Lemaire, M.; Schulz, J.; Kannappan, R.; Bucher, C.; Saint-Aman, E.; Chaix, C. Supramol. Chem. 2009, 21, 68-80.

29. Mendoza, S.; Godínez, L. A.; Kaifer, A. E. Supramol. Chem. 2004, 16, 165-169.

30. Frei, M.; Diederich, F.; Tremont, R.; Rodriguez, T.; Echegoyen, L. Helv. Chim. Acta 2006, 89, 2040-2057.

31. Nielsen, K. A.; Cho, W. S.; Jeppesen, J. O.; Lynch, V. M.; Becher, J.; Sessler, J. L. J. Am. Chem. Soc. 2004, 126, 16296-16297.

32. Lyskawa, J.; Sallé, M.; Balandier, J. Y.; Le Derf, F.; Levillain, E.; Allain, M.; Viel, P.; Palacin, S. Chem. Commun. 2006, 2233-2235.

33. Zhao, B. T.; Blesa, M. J.; Mercier, N.; Le Derf, F.; Sallé, M. J. Org. Chem. 2005, 70, 6254-6257.
34. Blesa, M. J.; Zhao, B. T.; Allain, M.; Le Derf, F.; Sallé, M. Chem. Eur. J. 2006, 12, 1906-1914.

35. Zhao, B. T.; Blesa, M. J.; Mercier, N.; Le Derf, F.; Sallé, M. Supramol. Chem. 2005 17, 465-468

36. Zhao, B. T.; Blesa, M. J.; Mercier, N.; Le Derf, F.; Sallé, M. New J. Chem. 2005, 29 $1164-1167$.

37. Garin, J.; Orduna, J.; Uriel, S.; Moore, A. J.; Bryce, M. R.; Wegener, S.; Yufit, D. S. Howard, J. A. K. Synthesis 1994, 489-493.

38. González, M.; Martín, N.; Segura, J. L.; Garín, J.; Orduna, J. Tetrahedron Lett 1998, 39, 3269-3272.

39. Yamada, A.; Murase, T.; Kikukawa, K.; Arimura, T.; Shinkai, S. J. Chem. Soc., Perkin Trans. 2 1991, 793-797.

40. Gautier, N.; Samuel, R.; Sahin, Y.; Levillain, E.; Leroy-Lhez, S.; Hudhomme, P. Org. Lett. 2004, 6, 1569-1572.

41. Le Bras, Y.; Sallé, M.; Leriche, P.; Mingotaud, C.; Møller, J. J. Mater. Chem. 1997 2393-2396.

42. Skibinski, M.; Gómez, R.; Lork, E.; Azov, V. A. Tetrahedron 2009, 65, 10348 10354.

43. Azov, V. A.; Gómez, R.; Stelten, J. Tetrahedron 2008, 64, 1909-1917.

44. Hardouin-Lerouge, M.; Hudhomme, P.; Sallé, M. Chem. Soc. Rev. 2010. doi:10.1039/b915145c. 